\title{
MERGULHANDO EM PROFUSÕES: ENTRE FEIRAS E IMAGENS DE FEIRAS, METODOLOGIAS POSSÍVEIS
}

\author{
Louise Maria Martins Cerqueira ${ }^{1}$ \\ Maria Angélica da Silva ${ }^{2}$
}

O fenômeno do gigantesco, da profusão, do excessivo, provoca inúmeras reações, do maravilhamento ao pavor. $\mathrm{Na}$ contemporaneidade, podemos aferir este transbordamento, por exemplo, no que tange aos universos não só materiais, mas também imateriais. Se as paisagens das grandes cidades acumulam chamados, letreiros, outdoors, automóveis, e multidões, por outro lado, tsunamis de informações adentram todos os dias o nosso cotidiano, trazidas pelos mecanismos usuais das redes digitais. Para além do conteúdo infinito, elas, as redes, cada vez mais, ousam explodir a superfície planar da tela, transbordando-se na superposição de informações e anúncios, ao ampliar esta superfície sob os efeitos em três dimensões.

Mas tal acúmulo informacional ecoa, de alguma forma, atividades muito antigas, também atravessadas pelo consumo, pela troca de informação, de negócios e novidades: as feiras e mercados. Os locais de compra e venda foram, por centenas e centenas de anos, lugares essenciais para a civilização. Foram sementes de organizações humanas que começavam itinerantes e depois, com o tempo, se estabilizavam em povoados, vilas e cidades.

Ao tratar das feiras livres, assoma ao imaginário um universo de cores, sons, cheiros, impossível de calar os canais sinestésicos da percepção. O que acontece quando este universo passa a ser registrado, em especial quando cerca de 11 pessoas o atravessa, portando câmeras fotográficas, com capacidade quase ilimitada de produzir registros?

Entre 2015 e 2016, o que foi possivelmente o mais vasto levantamento de referências culturais realizado no Brasil contemplou os 102 municípios de Alagoas. Tratou-se de uma etapa de Levantamento Preliminar, adotada pela metodologia desenvolvida pelo Instituto do Patrimônio Histórico e Artístico Nacional (Iphan) para abarcar

\footnotetext{
${ }^{1}$ Universidade Federal de Alagoas, Brasil. Email: luh.mmc@gmail.com ORCID id: https://orcid.org/0000-0001-7313-477X

2 Universidade Federal de Alagoas, Brasil. Email: mas.ufal@gmail.com ORCID id: https://orcid.org/0000-0002-2756-7627
} 
especialmente bens de natureza imaterial, o Inventário Nacional de Referências Culturais (INRC). Tal empreitada, intitulada Projeto de Salvaguarda do Patrimônio Imaterial em Alagoas ${ }^{3}$, gerou um imenso arquivo de fontes primárias composto por cerca de 20 relatórios, dezenas de fichas de inventário e mais de 12 mil fotografias e vídeos triados, os quais foram colhidos em visitas de campo.

Adentrou-se em um universo de anônimos mas que, de fato, não o são. E por um universo de imagens anônimas mas que, de fato, não as são. Será abordado, portanto, um acervo audiovisual de grandes proporções, que condensa, de alguma forma, os muitos modos de vida que foram acessados no contexto do projeto como um todo. Deste acervo, no que tange às imagens, cabe destacar que uma boa parte dele registrou as feiras livres, fenômeno que certamente chamava a atenção em qualquer das cidades onde se chegava, pelo seu vigor e por tangências com inúmeras manifestações de cunho cultural, portanto, com o objeto essencial da pesquisa.

O acervo de registro destas feiras que serve de fundo à análise que se procederá aqui, compõe-se de cerca de 2,8 mil fotografias, contemplando 39 feiras de 37 municípios ${ }^{4}$. Por muito tempo, a resposta, diríamos também fuga, para a indecisão diante da escolha de quais feiras livres aprofundar o estudo, foi olhar as imagens da coleção. Mas elas acabaram por roubar a cena. Fascinantes, variadas, foram aos poucos servindo como ícones daquele universo colorido que tanto extasiou os olhos dos pesquisadores em campo. Agora, longe do calor, do barulho, dos esbarrões, as feiras desfilavam caladas, uma após a outra, lado a lado, padronizadas em retângulos perfilados como batalhões, na tela de um computador. Contemplando-as desta forma, e tendo por trás o eco da vontade de ordenar, como é usual nas ciências ditas duras, o

\footnotetext{
${ }^{3}$ Este projeto foi financiado pelo Iphan em convênio com a Secretaria de Cultura do Estado de Alagoas e foi levado a frente por três grupos de pesquisa ligados ao Programa de Pós-graduação em Arquitetura e Urbanismo da Universidade Federal de Alagoas: Grupo de Pesquisa Estudos da Paisagem, Grupo Nordestanças, e o Grupo Representações do Lugar. A análise se debruça sobre o material do primeiro citado.

4 Trata-se dos seguintes municípios: Atalaia, Belo Monte, Boca da Mata, Branquinha, Cajueiro, Campestre, Campo Alegre (feira do Centro e feira do Distrito Luziápolis), Capela, Chã Preta, Colônia Leopoldina, Coruripe, Delmiro Gouveia, Flexeiras, Igreja Nova, Jacuípe, Japaratinga, Joaquim Gomes, Jundiá, Maragogi, Matriz do Camaragibe, Novo Lino, Passo de Camaragibe, Paulo Jacinto, Penedo, Piaçabuçu, Piranhas (feira do bairro novo e feira do Distrito Piau), Porto Calvo, Porto Real do Colégio, Quebrangulo, Roteiro, São José da Laje, São Luiz do Quitunde, São Miguel dos Milagres, Teotônio Vilela, Traipu, União dos Palmares, Viçosa.
} 
impulso foi de classificar. Seria melhor a organização por subconjuntos, a classificação por temáticas, pelos autores das fotos ou pelos locais a que pertenciam?

Contudo, a ordem com que se apresentavam na tela não calava a sua variedade de estímulos. E assim, acabaram por incitar (por que não?) a prática de uma deriva. Como os situacionistas faziam no passado, caminhando aparentemente sem rumo pelas cidades, agora o olhar poderia vaguear por ali, atravessando, contemplando, esbarrando naquela multidão de imagens ${ }^{5}$. Derivar por imagens, perder-se nelas. As andanças se deram como o fazem alguns antropólogos e etnógrafos em campo. Movidos por perguntas mas cientes do poder do imprevisto. Mas também recordando o flâneur benjaminiano, que caminha aberto às memórias que se sucedem. Os percursos iniciais se deram nos arquivos digitais como estavam organizados previamente, separados em pastas por lugar e contendo informações relacionadas à autoria e data dos registros. Como um catálogo fascinante, excitavam pela vivacidade cromática e pela amplitude das séries de objetos e corpos.

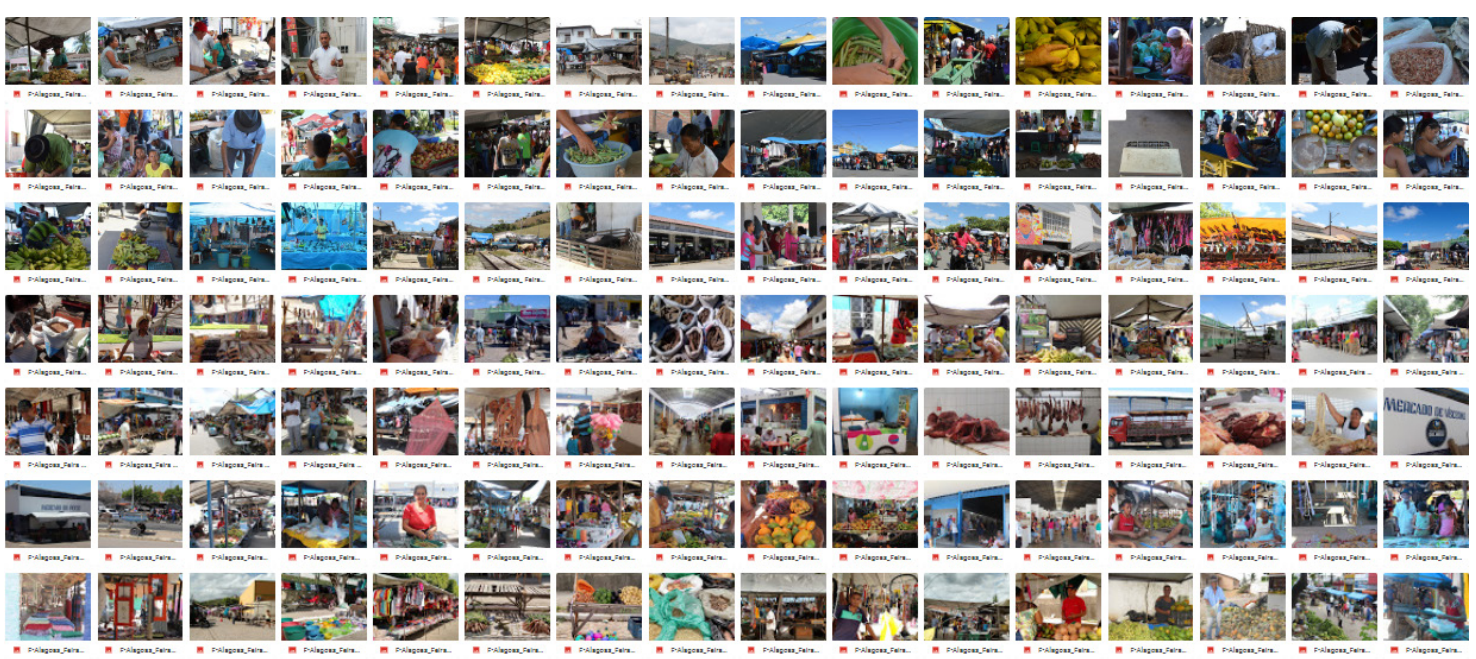

Imagem de parte do acervo fotográfico das feiras livres do Projeto de Salvaguarda do Patrimônio Imaterial de Alagoas. Fonte: Acervo Instituto do Patrimônio Histórico e Artístico Nacional - AL.

\footnotetext{
${ }^{5}$ A deriva está sendo entendida aqui enquanto método de aproximação com o objeto de estudo, do "perder-se" na cidade, como reportada na "Teoria da Deriva", onde na Revista Internacional Situacionista Guy Debord declarou-se que se refere à "afirmação de um comportamento lúdico-construtivo, o que torna absolutamente oposto às tradicionais noções clássicas de viagem e passeio" (Debord, 1958, apud JACQUES, 2003: 87) Em outras palavras: "A deriva é uma técnica do andar sem rumo. Ela se mistura à influência do cenário. Todas as casas são belas. A arquitetura deve se tornar apaixonante. Nós não saberíamos considerar tipos de construção menores. O novo urbanismo é inseparável das transformações econômicas e sociais felizmente inevitáveis. É possível se pensar que as reivindicações revolucionárias de uma época correspondem à idéia que essa época tem da felicidade. A valorização dos lazeres não é uma brincadeira. Nós insistimos que é preciso se inventar novos jogos." (Potlatch, 1954, apud Jacques, 2003) Propõe-se aqui uma "andança parada", movimentos de aproximação e afastamento entre os instantes congelados das fotografias.
} 
Mas a deriva pede o caos, a variedade, e, portanto, incomodava a ordem na tela do computador. Como proceder com esta enorme vitrine? Será que as imagens poderiam libertar-se da linearidade e, submetendo-se a um procedimento fiel ao campo analógico, fazerem-se materialidade? Esta foi, então, uma das decisões. O próximo passo foi aguardar ansiosamente que o pacote com todas as imagens impressas chegasse ao seu destinatário. E assim, as imagens, que substituíram espaços, acabaram, novamente, retornado ao caminho tátil e se tornaram superfícies que cabiam nas mãos.
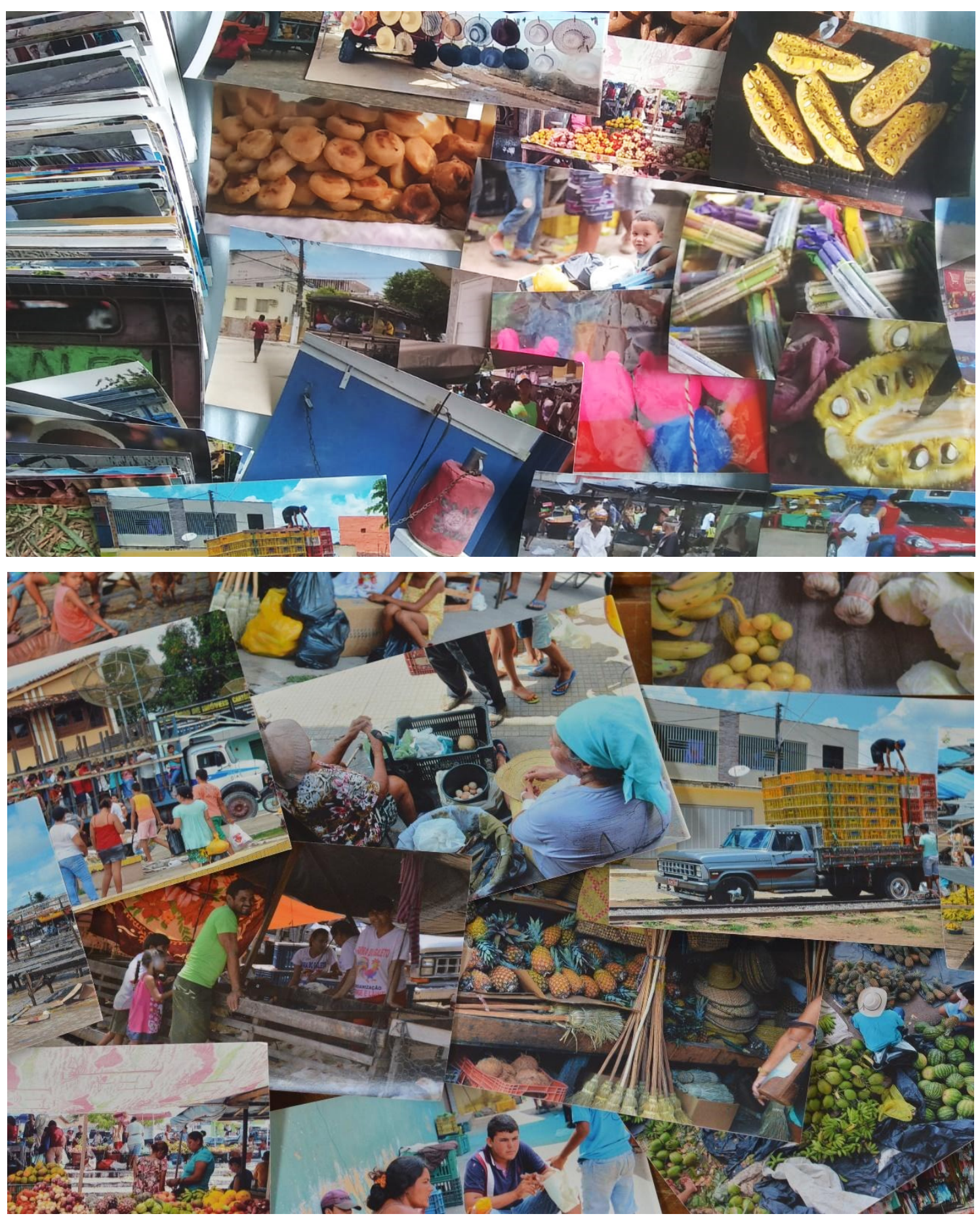

Fonte: acervo Grupo de Pesquisa Estudos da Paisagem. 
A partir daí, continuavam, contudo, os impasses. O que fazer com elas? Jogá-las como os dados de Mallarmé, ou como os contos da amarelinha de Cortázar? Ou adotar lógicas aparentemente estranhas como as das classificações fantásticas narradas por Foucault? Dentro de uma outra tradição de trabalho em pesquisa, o imponderável se fez ferramenta e parte do método. Uma das tentativas foi "desorganizar" as imagens, misturando-as.

Mas depois de assim, misturadas, o olho devia ainda percorrê-las uma a uma? Vastidão. Para olhar todas as fotografias de relance, cinco segundos mirando cada uma, se fariam necessários mais de catorze mil segundos. Mas as respostas começaram a vir das próprias figuras observadas. A fartura de imagens satura a vista, mas elas se fixam na mente e começam a povoar na memória do olho que não consegue parar e se deter em uma.

Para o poeta Manoel de Barros, o "reino da imagem" é o "reino da despalavra" (2010: 383). E parece que, com certas fotografias, quanto mais se fitava, mais difícil se tornava descrevê-las. Mas olhando apenas de relance, aos montes, elas pareciam assumir a forma dêictica a que Barthes se referiu:

Uma fotografia sempre se encontra no extremo desse gesto; ela diz: isso é isso, é tal! Mas não diz nada mais [...] a Fotografia é sempre apenas um canto alternado de "Olhem", "Olhe", "Eis aqui"; ela aponta com o dedo um certo vis-à-vis e não pode sair dessa pura linguagem dêictica. (Barthes, 2006: 14)

Aqui não se trata, apenas, da profusão de imagens, mas, e principalmente, de imagens da profusão. Tudo aos montes e em variedades, cores, pessoas, objetos, elementos espaciais.

Eis, de vislumbre, as barracas, normalmente de madeira, nas quais os produtos são dispostos, os peixes são tratados, as pessoas se sentam. E muitas caixas, de plástico e de madeira, aqui e ali. De repente, lonas forrando o chão, ou fazendo o papel de cobertas, pretas, amarelas, alaranjadas, azuis, brancas, verdes... amarradas, rasgadas, remendadas, substituídas por materiais outros. Sobre os objetos e pessoas, a luz colorida emana, pigmentando os ares. 
Afora os produtos que, diversos e com frequência, aparecem dispostos no chão ou pendurados. Predominam alimentos. Amontoados de frutas: das pequenas ciriguelas, das uvas e laranjas, dos limões, às obesas jacas e melancias, in natura ou já abertas para que os compradores possam provar e, seduzidos, queiram levar. E legumes: batata, batata doce, cenoura, abóbora, chuchu. Colorau e cominho se fazem presentes, junto com outros temperos e o vermelho das carnes chama atenção.

Guiando os carrinhos de mão, crianças. Com lenços e chapéus nas cabeças, os idosos. Homens e mulheres negociam, conversam. Os galpões concentram produtos por tipo: cereais num, carnes noutro. Despontam padrões, elementos que se repetem: chãovitrine, chão-refugo; caixa-vitrine, caixa-banco, caixa-transporte; carrinho-de-mãovitrine, carrinho-de-mão-transporte, carrinho-de-mão-banco; barraca-vitrine, barracabanco. A feira, ou feiras, constroem-se num avesso da arquitetura ofertada por arquitetos, assomando em uma montagem de objetos, de disposição, de intervenções, de gambiarras. São imagens reconfigurando o mundo da imaginação.

Continuam despontando padrões, gestos que são reproduzidos por diferentes corpos aqui e ali e que se encurvam para debulhar feijão, que agacham para apalpar o produto amontoado no chão, que degustam, que pesam, que carregam, que pagam, que conversam, que jogam. Galinhas são transportadas de ponta-cabeça; sacolas carregadas em cima da cabeça. Caminhões do tipo pau-de-arara. Animais que são transporte, animais que são domésticos, animais que são bichos, ou que são apenas alimento, até mesmo se reduzidos às vísceras. Vivos, mortos, ou em pleno processo de abate, realizado sem cerimônia no meio da rua.

Junto a essa profusão de estímulos, outras ideias se associam: o caçuá remete aos saberes do artesanato de cipó; o chapéu, do artesanato de palha; a panela de cerâmica, de barro; a cocada, do tirador de coco; a macasada, da casa de farinha; o raizeiro, dos saberes medicinais e dos curandeiros; e a freguesia, de quase todos aqueles que foram entrevistados em campo pelo Projeto de Salvaguarda. E de tudo isso, de cada uma dessas órbitas em torno da feira, um outro acervo imagético atrelado, que se avizinha. Todo este universo entra pelos olhos e pela memória. E assim o acervo transborda as duas mil e oitocentas fotografias, desenquadra-se do recorte que já era imensidão. 
Quando este conjunto imagético se abre para o desses cotidianos atrelados, amplia-se, ao mesmo tempo em que se adensa, porque parece que às imagens assoma então o mundo das recordações as quais elas se associam. E não consegue barrar a memória do campo, da experiência das entrevistas, as de outras fotografias. De fato, estas últimas, ao mesmo tempo se submetem e se rebelam. Associam-se também a um acervo de sentimentos e percepções. Então foi preciso refletir sobre a natureza horizontal dessa etapa de embaralhamento com as imagens e do próprio Projeto de Salvaguarda como um todo. Ponderar sobre esse mosaico de conhecimentos em pequenos fragmentos, que se construiu em experiências pessoais, mas também por tabela, nas trocas internas das equipes, e nas leituras posteriores dos documentos. E isso gerou uma imagem conceitual da experiência no projeto e da experiência com o acervo baseada na ideia de superficialidade, ela profunda, ela profusa, ela densa ${ }^{6}$.

Então, não estava mais em vista apenas dois vetores: horizontalidade e verticalidade, como apenas compreendido através das dualidades geral versus específico, panorâmico versus detalhado, superficial/raso versus profundo. Tratava-se de se desvencilhar, por uns instantes, do senso comum que atribui à ideia de superfície como incipiente, fraco, em contraposição à ideia de profundidade como denso e complexo. Também extrapolava qualquer ideia da superfície como farsa, máscara do verdadeiro interior. E assim, o processo de embate com as imagens se fez ecoar na seguinte passagem de Didi-Huberman:

Há superfícies que transformam o fundo das coisas ao redor. Os filósofos que transformam o fundo das coisas ao redor. Os filósofos da ideia pura, os místicos do tabernáculo não pensam a superfície senão como uma maquiagem, uma mentira: o que esconde a essência verdadeira das coisas. Aparência contra essência ou semelhança contra substância, em suma. Podemos pensar, ao contrário, que a substância decretada para além das superfícies não passa de um embuste metafísico. Podemos pensar que a superfície é o que cai das coisas: que advém diretamente delas, o que separa delas, delas procedendo, portanto. E que delas se separa para vir rastejando até nós, até a nossa vista, como retalhos de uma casca de árvore. Por menos que aceitemos nos abaixar para recolher alguns pedaços. A casca não é menos verdadeira que o tronco. É inclusive pela casca que a árvore, se me atrevo a dizer, se exprime. Em todo caso, apresenta-se a nós. Aparece de aparição, e não apenas de aparência. A casca é irregular, descontínua, acidentada. Aqui ela se agarra à árvore, ali se desfaz e cai em nossas mãos. Ela é a impureza que advém das coisas em si. Enuncia a impureza - a contingência, a variedade, a exuberância, a relatividade - de toda coisa. Mantém-se em algum lugar na interface de uma aparência fugaz e de uma inscrição sobrevivente. Ou então designa, precisamente, a

\footnotetext{
${ }^{6}$ Estas outras possibilidades de adestrar imagens e ser adestrado por elas vêm sendo trabalhadas na tese de Louise Cerqueira, em andamento junto ao Programa de Pós Graduação em Arquitetura e Urbanismo da Universidade Federal de Alagoas.
} 
aparência inscrita, a fugacidade sobrevivente de nossas próprias decisões de vida, de nossas experiências sofridas ou promovidas. (Didi-Huberman, 2017: 70-71)

Aventa-se que a complexidade pode encontrar, no estudo embalado pela amplitude, pelos excessos, pela profusão, também fertilidade: não seria preciso um solo muito fundo para a terra dar frutos, mas sim um solo fértil. O superficial entendido como o vasto, a profundidade que se deita, que se espalha. Ambos podendo conter-se em si.

Aqui, faz-se uma defesa da superfície ou da vastidão como etapa metodológica de possibilidades frutíferas, e não apenas rasas. Mas, afinal, não é qualquer superfície a que aqui se deseja: a superfície desejada é a que pode conter ampla inervação, ou que nos desperta para a nossa natureza sensível, em movimento contínuo.

Então, a relação com as feiras, aqui, dá-se no embate entre corpos que pesquisam e corpos pesquisados, que olham e são olhados, mesmo que o principal envolvimento seja o do olhar quase solitariamente as imagens. Que demanda pensar as feiras e o ato de pesquisá-las em um sentido de ação. De materialidade que pode ser mais que receptáculo para o simbólico, possivelmente em tangência com a visão de patrimônio compreendido no seu campo ativo: "Afinal, os seres humanos usam seus símbolos sobretudo para "agir" e não somente para se "comunicar". O patrimônio é usado não apenas para simbolizar, representar ou comunicar: ele é bom para agir. [...] Ele, de certo modo, constrói, forma as pessoas." (Gonçalves, 2007: 114). No âmbito desta forma de compreensão, a materialidade deixa de ser coadjuvante e pode ser interpretada como abrigo de potência própria para reflexões, não apenas como ponte para outras categorias analíticas mais abstratas.

Objetos materiais e técnicas corporais, por sua vez, não precisam ser necessariamente entendidos como simples "suportes" da vida social e cultural (como tendem a ser concebidos em boa parte da produção antropológica). Mas podem ser pensados, em sua forma e materialidade, como a própria substância dessa vida social e cultural. (Gonçalves, 2005: 22-23)

Destarte, parte-se aqui da compreensão de que a materialidade é mais que suporte de significados, mas abrange sensorialidades, motricidades. Além disso, do entendimento que sujeito e corpo estão implicados no fazer pesquisa, e que o campo do 
sensível abriga potências, mesmo quando consideradas imprecisas ${ }^{7}$. Concebe-se "o elo inseparável entre o observador e a coisa observada" ${ }^{8}$ (Morin, 2011: 12).

$\mathrm{O}$ gesto de pesquisa demonstra ele próprio, serem sujeito e objeto sempre engrenados. Não há sujeito com objeto, mas é a relação concreta do gesto da pesquisa, da qual sujeito e objeto são conceitos ideológicos extrapolados do gesto concreto da pesquisa. (Flusser, 2014: 47)

Quando se escolhe o caminho em que a subjetividade está tão implicada, pensar o próprio corpo - desde características físicas e papeis sociais a medos, sonhos e anseios - passa a ser componente essencial. Não apenas a visão, mas todos os sentidos passam a demandar espaço na construção de narrativas.

Também se faz preciso refletir sobre as demandas diferenciadas para uma leitura de imagens e uma leitura de palavras. Então as narrativas despojadas de palavra podem encontrar, para além do que podem fazer os escritos textuais que buscam decifrá-las, força enunciadora na própria forma de se apresentarem. Por isto a necessidade de elaborar um ensaio visual.

Chegou o momento de reavaliar - serena e seriamente - a epistemologia da comunicação, ameaçada na dubitável matriz logocêntrica de nosso Ocidente. O verbal escrito instaurou-se como ordem epistemológica e fizemos tanto da fala quanto da escrita as crenças (para não falar em dogmas) e as alavancas de nossas faculdades de apreensão e intelecção. Não é somente possível como necessário livrar-nos dessa epistemologia da comunicação, que ignora, enquadra e reduz a indizibilidade e a riqueza polissêmica do sensorial humano. Depois de Aristóteles, Tomás de Aquino tinha razão, no século XIII, de lembrar aos seus contemporâneos, os novos letrados, que "nada há no intelecto que não tenha estado nos sentidos". (Samain, 2012)

Contudo, este não é um desafio fácil. Deslocar a imagem da função de simples ilustração ou de "prova"9 (Dubois, 2012) do que está mencionado no escrito, como foi durante muito tempo o uso da fotografia nos trabalhos acadêmicos, exige esforço.

\footnotetext{
7 "Os saberes do corpo foram considerados demasiado imprecisos para garantir o conhecimento da verdade. [...] A racionalidade moderna produziu um saber fragmentado sobre o corpo, muitas camadas superpostas em forma de discursos variados que tentaram silenciar a sabedoria do corpo e sua linguagem sensível. Porém, esses saberes permaneceram, de modo silencioso e ativo, nas sombras do inconsciente, do irracionalismo, ou quaisquer outros nomes que tenham inventado para deixá-lo longe dos caminhos da racionalidade. Não poderia ser diferente, pois o corpo é nossa condição existencial. A vida é um processo cognitivo, desde os níveis mais elementares até as formas mais complexas, como os seres humanos. A cognição emerge da corporeidade, da dinâmica dos processos corporais. A tradição ocidental, de um modo geral, considerou esse saber como irrelevante ou acessório.” (Nóbrega, 2010: 31-34)

8 "A inteligência cega destrói os conjuntos e as totalidades, isola todos os seus objetos do seu meio ambiente. Ela não pode conceber o elo inseparável entre o observador e a coisa observada. As realidadeschaves são desintegradas. Elas passam por entre as fendas que separam as disciplinas.” (Morin, 2011: 12)
} 
No entanto, antes de adentrar a especificidade deste nosso ponto de partida, a fotografia inicial, Boris Kossoy (2001) nos adianta dois desafios incontornáveis ao lidar com a imagem fotográfica como lugar de problematização para uma pesquisa de caráter histórico: primeiro, o fato de existir um "aprisionamento multissecular à tradição escrita como forma de transmissão do saber [...]; nossa herança livresca predomina como meio de conhecimento científico". (Kossoy, 2001, p.30) Segundo, o fato de, por conta desse iletramento visual, a imagem configurar-se como um obstáculo, já que a informação não é "transmitida segundo um sistema codificado de signos em conformidade com os cânones tradicionais da comunicação escrita". (Kossoy, 2001: 30). (Mortimer, 2018: 159)

Portanto, seguiu-se com o trabalho com as fotografias deixando que o embate com o acervo alimentasse as reflexões sobre o poder do visual e da imagem, e que este embate germinasse, por fim, uma narrativa puramente visual. Apresentam-se, aqui, algumas reflexões iniciais, começando com uma narrativa sobre a relação do visual com um outro sentido muito evocado na experiência das feiras livres: o olfato. Colocam-se de fato como etapa preparatória para o exercício visual, outros temas como o papel da marca escrita na feira, as temporalidades, as trocas visivas, a fartura e a escassez e, por último, o papel da imaginação, acreditando que sua fruição pode despertar em quem olha o que as lacunas do raciocínio escrito não pôde evocar, e acreditando que "toda imagem (...) nos oferece algo para pensar: ora um pedaço do real para roer, ora uma faísca do imaginário para sonhar.” (Samain, 2012).

\section{Entrando no jogo das percepções e amputando um sentido: a feira anósmica}

Quando a feira, o comércio, o alimento, saem das ruas e ganham abrigo nos shopping centers, nas grandes redes de supermercados, tornam-se espaços da luz quando a luz é entendida como "síntese entre técnica e ação subjacente às propostas de evolução, progresso e controle dos aspectos mais renegados da existência" (Ribeiro, 2012: 66) Tornam-se também espaços “desodorizados”. Nesse sentido, as feiras livres, entendidas aqui como "espaços opacos" (Ribeiro, 2012) parecem ser a antítese daqueles de "silêncio olfativo" (Corbin, 1987: 10). Pois é inegável o seu apelo sinestésico, também embaralhado e múltiplo, que coloca em colisão todos os canais perceptivos.

\footnotetext{
9 "Nela a necessidade de "ver para crer" é satisfeita. A foto é percebida como uma espécie de prova, ao mesmo tempo necessária e suficiente, que atesta indubitavelmente a existência daquilo que mostra". (DUBOIS, 2012: 25)
} 
Pois feiras são um acúmulo de compostos aromáticos diversos advindos de corpos nas suas mais variadas expressões. São corpos vivos - bichos, animais. Jegue, burro, cavalo, boi, porco, bode, cachorro, galinha, peru, moscas, abelhas, formigas, tanajuras. São corpos mortos - tripas, vísceras, carnes, frutos do mar. A estes se somam restos orgânicos espalhados pelo chão e matérias que alimentam corpos: pasteis fritos, cana moída na hora e bagaço jogado no chão, rapadura, quebra-queixo, tapioca assada, bolachas, vegetais frescos... E além disto, todo um assomo de objetos que o corpo demanda: brinquedos de plástico, sandálias e objetos de couro, velas, ervas... Madeira usada, plástico novo, plástico velho. O cheiro do suor quente ou das águas da chuva e suas poças, córregos que espalham fedores e aromas. Amalgamados? Ou discerníveis?

Como ficam as feiras livres diante da "ofensiva contra a intensidade olfativa do espaço público" (Corbin, 1987: 10)? Se "o dejeto nauseabundo ameaça a ordem social”, enquanto "a reconfortante vitória da higiene e da suavidade acentua a sua estabilidade", (Corbin, 1987: 11), como fica a percepção dos odores das feiras livres, principalmente quando em contraste com a "limpeza" dos supermercados, climatizados, saneados desodorizados? O que essa ausência de odores implica?

Mas aqui, parte-se de outra espécie de ausência de cheiros. Anosmia é a inexistência completa do sentido do olfato ${ }^{10}$. Se "de todos os sentidos, o olfato é o menos compreendido" (Malnic, 2012: 09) ${ }^{11}$, que dizer então da sua ausência? Se as feiras são esse acúmulo de compostos odoríferos, que dimensão da experiência se altera quando um corpo não apresenta a capacidade de sentir cheiros?

Olhar fotografias é, numa primeira análise, da realidade subtrair os sons, os cheiros, a profundidade, a qualidade tátil. Mas, se a abundância de elementos parece aludir à profusão desses outros sentidos, ainda assim a experiência de um corpo anósmico peculiariza o embate com a ausência de cheiros da fotografia.

\footnotetext{
${ }^{10} \mathrm{O}$ interesse de uma narrativa dos cheiros a partir da perspectiva de um corpo anósmico se deu em função da incapacidade de senti-los por parte da primeira autora deste artigo. Soma-se à condição o fato de sempre se deparar com muitos comentários acerca da importância do cheiro da feira; seja de tom negativo ou positivo, sempre são enérgicos.

11 "De todos os sentidos, o olfato é o menos compreendido. Historicamente, grandes esforços foram dedicados ao longo dos anos para o estudo dos outros sentidos, como a visão ou a audição. (...) Essa falta inicial de interesse, provavelmente, se deveu ao fato de que, em geral, sempre se acreditou que o homem tem um olfato empobrecido, principalmente quando comparado a outros animais." (Malnic, 2008: 09)
} 
Por este motivo, apenas guiando-se pela questão dos cheiros, questionou-se, inicialmente, que possível dimensão se perderia na vivência desses espaços. Mas uma simples pergunta desestabilizou essa inquietação e a substituiu por outra: será possível para um corpo anósmico ver o cheiro da feira?

Aventou-se então a possibilidade de que a mera falta na verdade poderia ganhar outros contornos. Um corpo anósmico constrói, a sua maneira, um repertório, uma coleção de fragrâncias. O odorante não se desprende da matéria para ser captado pelos milhares de receptores em seu nariz, mas a matéria evoca uma imagem de cheiro construído "por tabela", um repertório olfativo alimentado através de outros corpos: é porque outras pessoas reagem aos odores que eles são coletados e categorizados mentalmente. Nesse tocante, ganha relevo a dimensão ótica.

Tal condição, portanto, não se resume a uma simples deficiência, mas implica numa ordem reversa do fenômeno olfativo: ao corpo anósmico, cheiros não anunciam coisas, mas coisas enxergadas anunciam ideias de cheiro. Constrói-se um acervo de olores através da experiência de terceiros e mapeia-se através da imagem que o corpo faz do que eflui ao redor.

E o olhar se torna um exercício de mapeamento de cheiros. Veem-se os cheiros da feira através das fotografias. É a construção social do que antes era interpretado como uma simples ausência corporal.

\section{Marcas, inscrições}

Olha-se o acervo. Aqui e ali, letras e números. Caixas e barracas com nomes ou siglas pintadas denotam posse de objetos. "Zé Augusto da Verdura". "Sales". "Didiu 25". "Cleide". As informações se assomam nos objetos.

Mas há também aparentemente as marcas menos rígidas, que podem ser registradas em fotografia de modo sutil, como o desenho que os dedos fazem nas superfícies das farinhas ensacadas por parte daqueles consumidores que, ainda hoje, têm o costume de pegar um punhado desta para provar antes de comprar. 


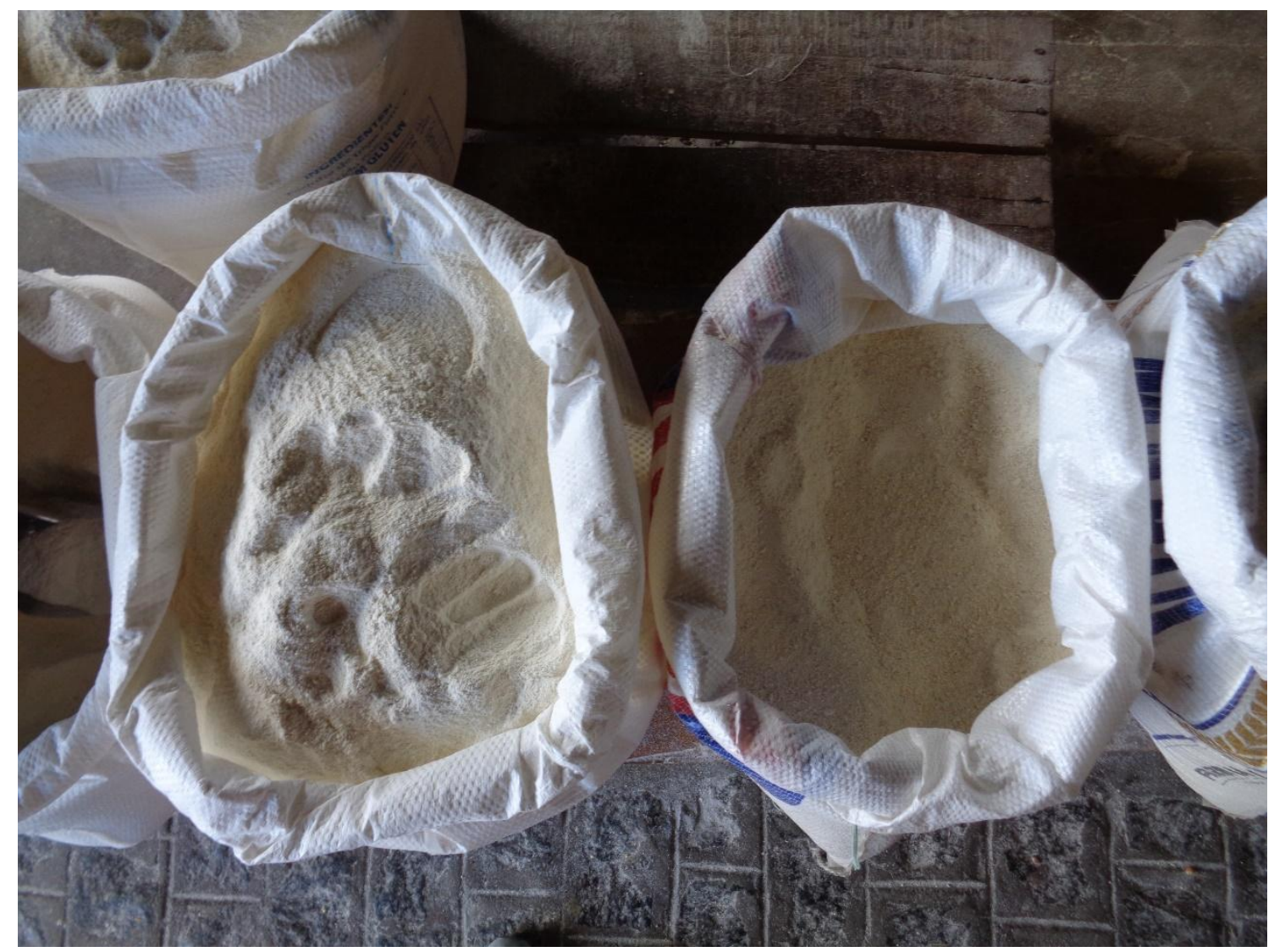

Autoria: Janaína Toscano. Fonte: Grupo de Pesquisa Estudos da Paisagem.

A fotografia pode mostrar apenas as supostas marcas dos dedos, mas também a mão que, hipoteticamente, faz uma marca. Contudo, até onde a fotografia mostra o que parece mostrar? Até onde completamos com a imaginação, com a intuição, ou com um "método indiciário" (Ginzbourg, 1989)? Como separar, no olhar de imagens, com toda sua contingência, a hipótese da dedução? Como enxergar tenuidades? 


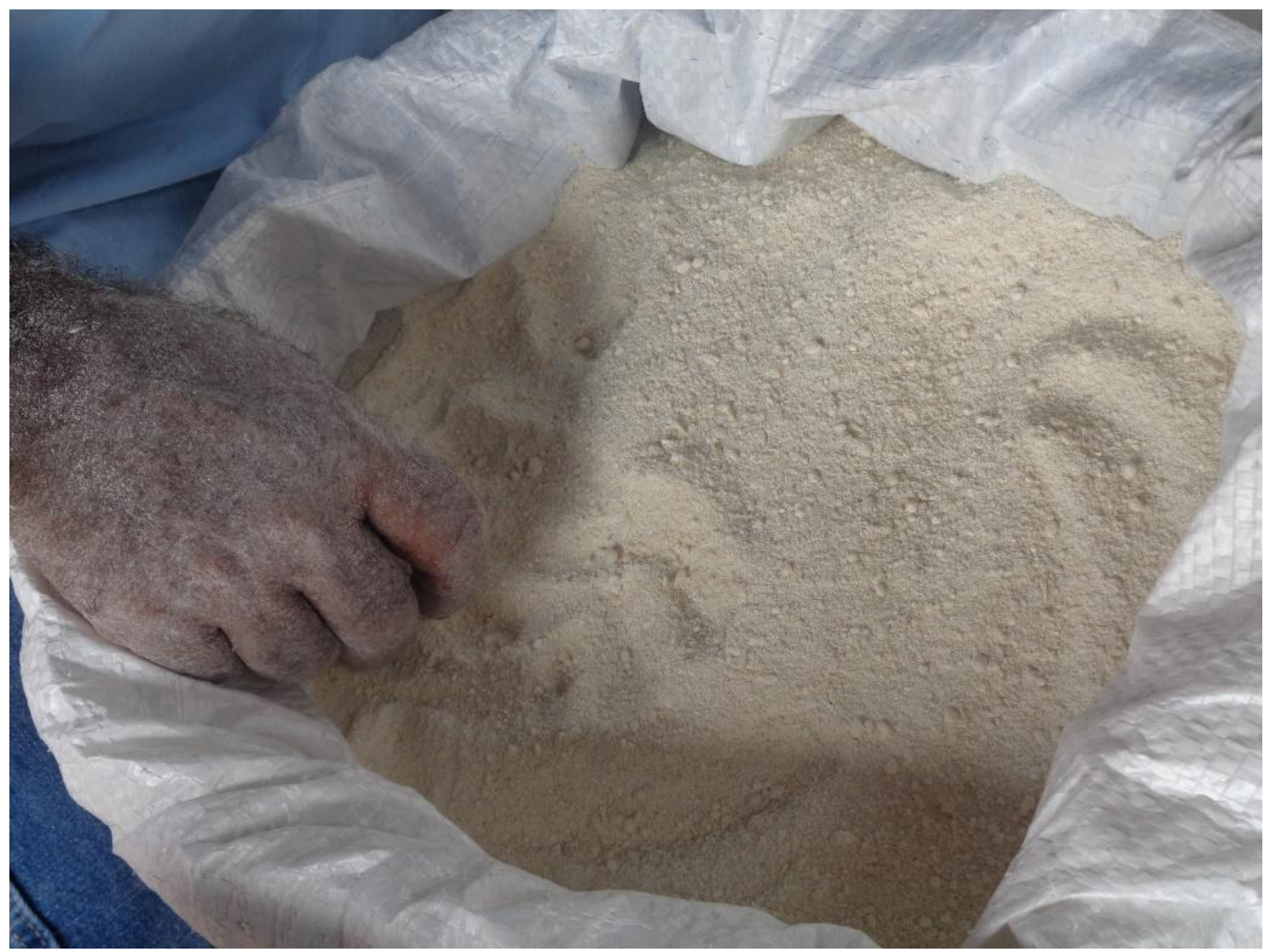

Autoria: Karina Mendonça. Fonte: Instituto do Patrimônio Histórico e Artístico Nacional - AL.

\section{Tempos e deslocamentos}

$\mathrm{Na}$ feira, os tempos se misturam, coexistem os modos arraigados junto à tecnologia, ao industrial, ao made in China. É quase como se os tempos se acumulassem junto aos objetos e entulhos. A despeito das novas regulações ambientais, gaiolas de passarinhos são vendidas e também filhotes de galinha pintados de cores extravagantes. Nos meios de transporte, o carro de boi, o jegue e o cavalo dividem espaço com o paude-arara cheio, os caminhões e as motos. 
As diversas temporalidades e velocidades das feiras se mostram nas imagens através dos elementos que podem atuar como signos de um tempo. Por isso, o olho vaga e procura definir, encaixar, categorizá-la em um período, um ritmo, uma hierarquia temporal. Porém, ela é o tempo do rural com os quitutes das casas de farinha motorizada. Tempo do chapéu de palha e do boné, da vestimenta de couro e das roupas com estampas em inglês, dos fogos de artifício caseiros e estilingues bem como bonecos da Peppa Pig. Do fumo de corda e dos DVDs. É a mistura de tempos que não necessariamente competem, mas se imbricam de forma mais complexa que qualquer dualidade entre "tradição" e "modernidade" se desfaz.

Partindo do pressuposto que cada "tempo" é marcado por uma tecnologia e modos próprios, ainda assim o embate entre as várias escalas do urbano e as várias escalas do rural, as diferentes velocidades, apontam para um tempo que é capaz de abrigar várias temporalidades. Mas essa coexistência de signos e tempos distintos pode também colocar em xeque o que consideramos predominante, e predominante para quem? E então perceber onde estão nossos pressupostos de tempo, descortinando formas de olhar, posturas diante do acervo.

Poderíamos dizer que identificamos, em sua maioria, jornadas "dos homens de tempo lento" 12 , ainda que em situações híbridas, mesmo que atravessadas de alguma forma nada tímida pelos ideais de modernidade e velocidade?

\section{Olhares}

O sentimento desperto em quem fita uma fotografia é circunstancial e individual, mas não é apenas deliberado pela subjetividade. Também é suscitado pelas formas inscritas na superfície fotográfica. Como Samain instigantemente coloca:

\footnotetext{
12 "O que existe são temporalidades hegemônicas e temporalidades não hegemónicas, ou hegemonizadas. As primeiras são o vetor da ação dos agentes hegemônicos da economia, da política e da cultura, da sociedade enfim. Os outros agentes sociais, hegemonizados pêlos primeiros, devem contentar-se de tempos mais lentos". (Santos, 1996: 13) Ana Clara Ribeiro explora a expressão e afirma que "o homem lento [...] - que é o homem dos espaços opacos da cidade - cria formas alternativas de sociabilidade e táticas de sobrevivência" (Ribeiro, 2009: 152)
} 
As imagens pensam e nos fazem pensar, além de elas moldarem o nosso próprio olhar. Somos assim "observadores" condicionados tanto pelos nossos modos de ver como pela peculiaridade com que as imagens olham para nós. (SAMAIN, 2012)

A "peculiaridade com que as imagens olham para nós".

No embalo dos olhares, os vemos aos montes no acervo e, em alguns casos, sentimo-nos por eles olhados de volta. Em alguns exemplos, são acompanhados de um riso, noutros, encaram o fotógrafo. De todos os olhares das fotografias que se encontram no último caso, um se tornou provocativo, parecendo demandar que o olhássemos com mais atenção. De sobrecenho, duas mulheres, no meio de uma foto, fitam com olhar intrigado a máquina. Ou a fotógrafa? Ou a fotografia? Fitam-nos, a nós, que a enxergamos através da película, na distância? Franzem a testa, e esse gesto enrugado não passa despercebido, pode desestabilizar um olhar demorado.

Franzem como quem pergunta o motivo do interesse em sua pessoa. Ou como se questionassem a transposição que o clique causaria, de sujeitos para objetos de escrutínio. Quando se interpreta tal expressão facial nesse sentido, o olhar passa a pungir. Diríamos, por fim, que esse cenho, esse olhar, parece agir sobre nós como punctum, nos termos de Barthes. Causa desconforto, comoção. Parece questionar o direito à própria imagem. 


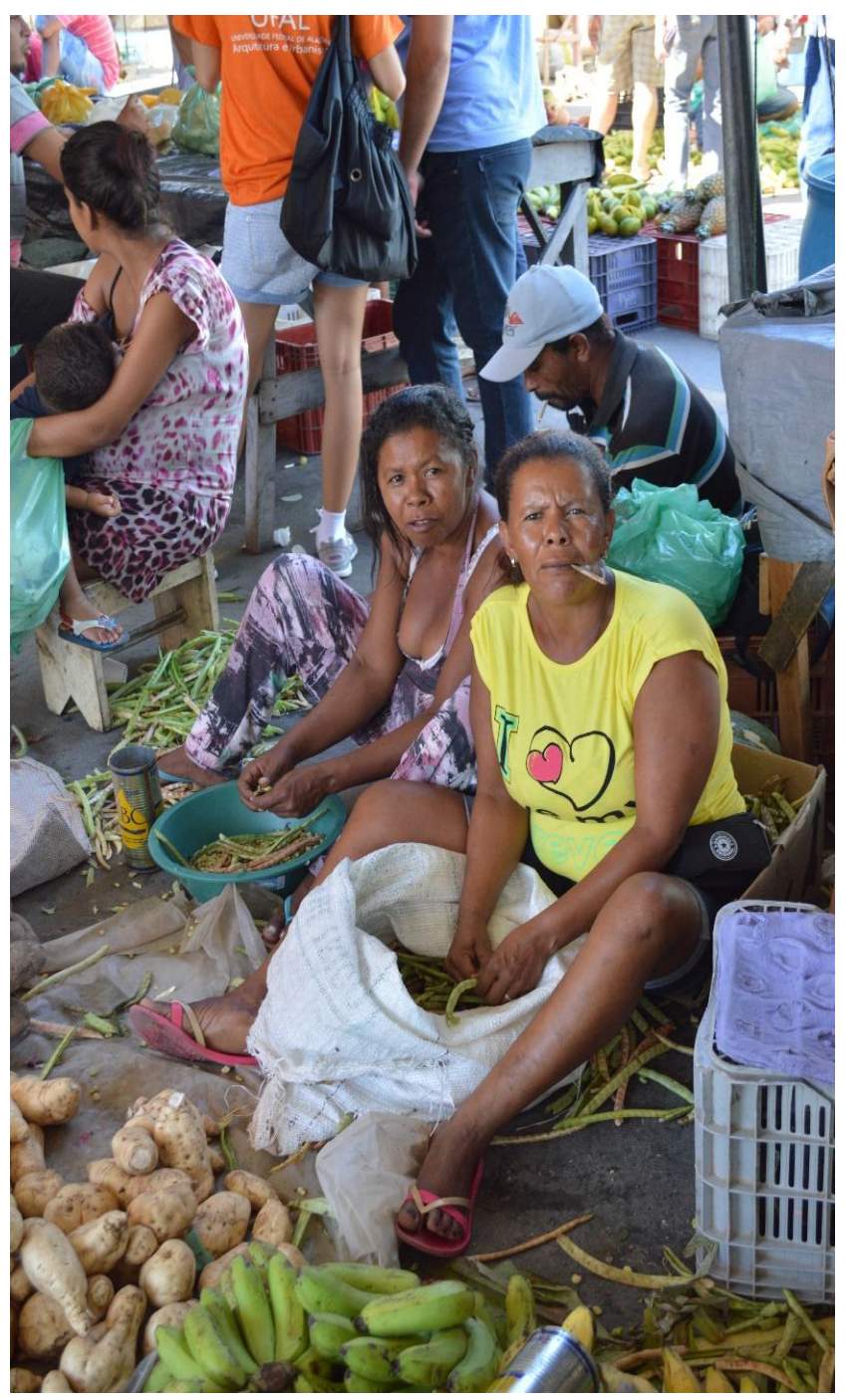

Autoria: Ana Karolina Corado. Fonte: Acervo Instituto do Patrimônio Histórico e Artístico Nacional -

AL.

Há também olhares que se apresentam posados. Dentre eles, os de alguns entrevistados, que mostram, nas fotografias, um certificado de participação, feito pelo grupo de pesquisa como forma de agradecimento. Não foram pegos de surpresa, parecem à vontade com a câmera. Essa foi uma das saídas encontradas pelo grupo para diminuir o constrangimento da partida a cada fim de entrevista, momento no qual, depois de termos aprendido com os depoentes, ainda teríamos que colher a assinatura do termo de cessão de imagem. A sua imagem, cedida, nós a levávamos conosco... Empilhadas em terabytes de computador. O que ficava com eles? Por vezes, um aparente sentimento de reconhecimento. Noutros casos, a lembrança do que nossas perguntas os faziam recordar... E um pequeno gesto de gratidão diante da muitas vezes generosa forma de se entregar ao rápido encontro por parte deles, entrevistadosimagens. 


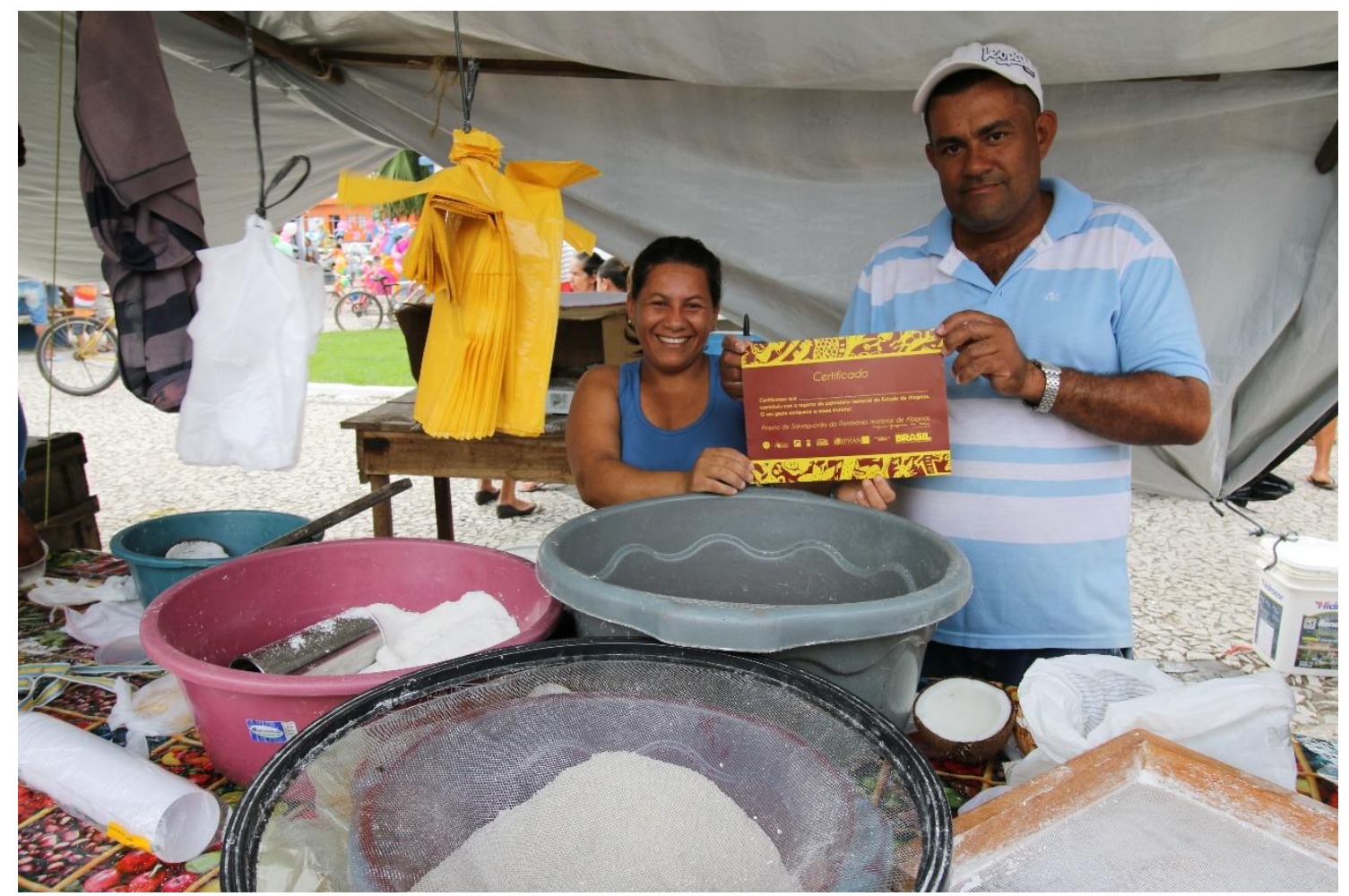

Autoria: Flávia Correia. Fonte: Acervo Instituto do Patrimônio Histórico e Artístico Nacional - AL.

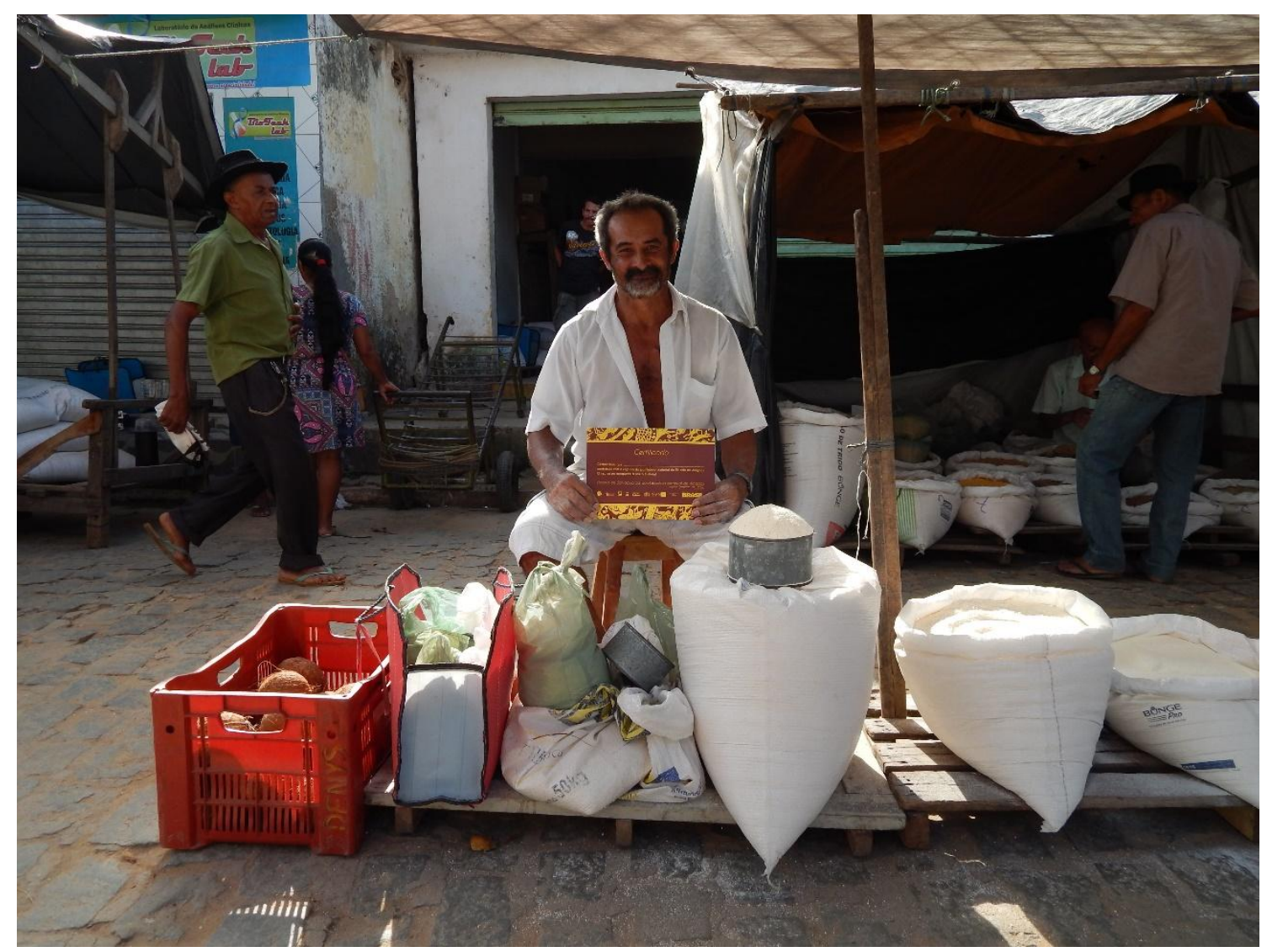

Autoria: Paula Louise Fernandes. Fonte: Grupo de Pesquisa Estudos da Paisagem. 


\section{O parco que não está lá}

Já foi enfatizada a profusão que emana do acervo e das feiras, mas não seu completo oposto: a escassez. As feiras são também lugares em que o pequeno agricultor rural pode vender o excedente de uma produção majoritariamente de subsistência. Além disso, há a escassez que as fotos pouco revelam, porque a feira, como se ciosa do seu pacto com o farto e o generoso, pouco permitisse revelar. As imagens aludem aos objetos que lá existiam, aos produtos que lá se apresentavam. Mas não aos peixes que não foram pescados em um dia adverso, nem às casas de farinha que foram desativadas porque o trabalho árduo não compensava financeiramente. A profusão distrai do contrário da fartura que existe por trás de muitas feiras.

Mas tudo isso fica, muitas vezes, escondido da fotografia. É preciso, às vezes, por conseguinte, saber para poder ver (em oposição à sabedoria popular que pede o ver para crer).

Mas e quando isso fica escondido não da fotografia, mas na imagem? Nesses casos, um olhar atento ao acervo pode entrever tais nuances. Em uma fotografia, a escassez se faz notar com um tom de ironia. Um detalhe que, depois de notado, transforma a imagem, torna-se muito mais que uma informação do fundo da cena. Podemos decodificá-la, mas o que a ironia pode implicar desestabiliza emocionalmente. Uma senhora sorri, aparentemente tímida, desviando o olhar da foto. Ela tem um lenço na cabeça, e segura uma sacola; na sua frente, um carrinho de mão com mais alguns pacotes. Nos fundos, um homem está por detrás de uma barraca e segura o que parece uma batata com a mão direita. Ele olha diretamente para a câmera. Mas é a inscrição na coberta de sua barraca que pode causar inquietação a um olhar sensível: reaproveitada, reciclada, pode-se ler, de trás para frente e com as letras de cabeça para baixo, as palavras "PARA INVESTIMENTO”. 


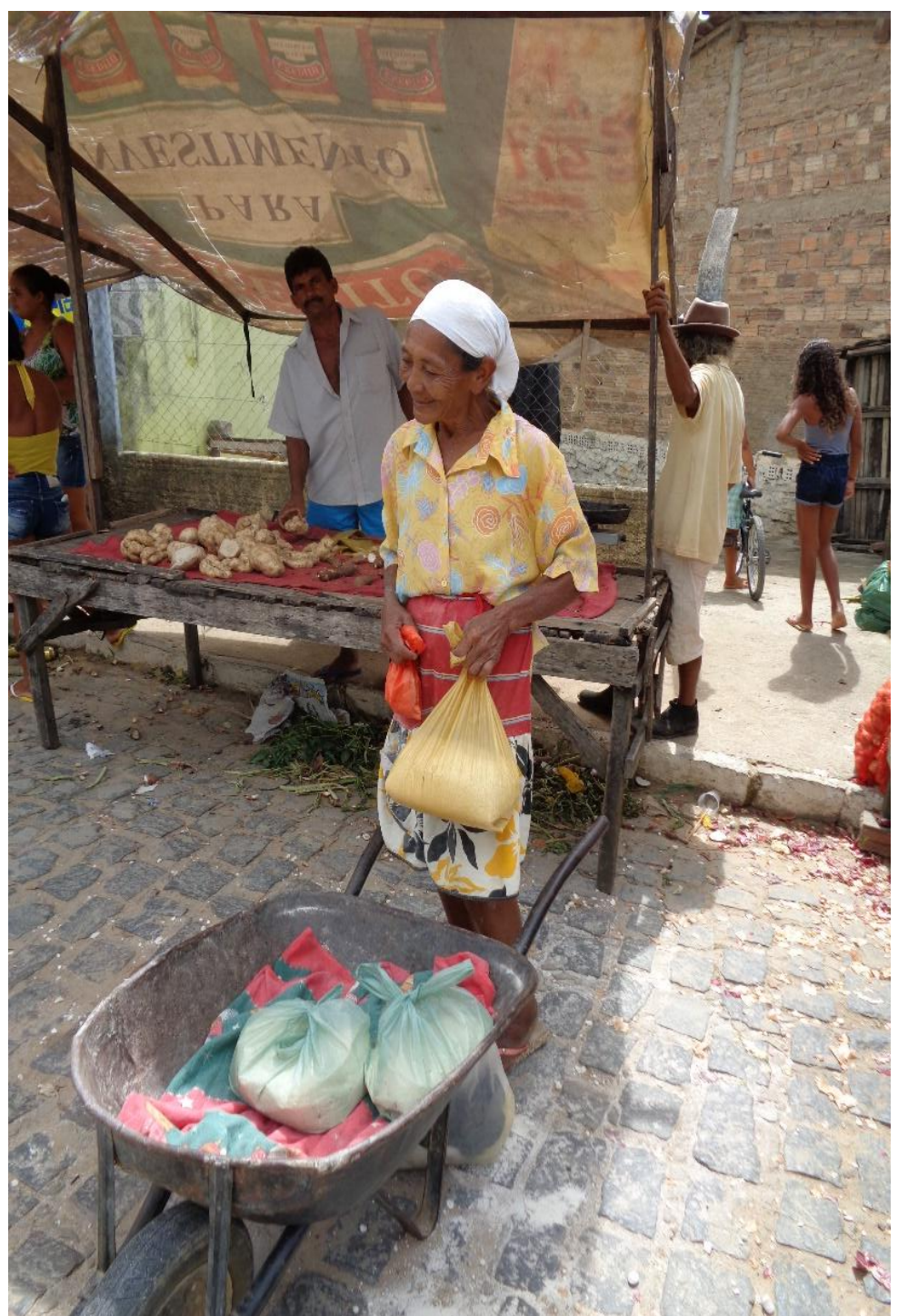

Autoria: Ludmila Mares. Fonte: Acervo Instituto do Patrimônio Histórico e Artístico Nacional - AL.

\section{Dilacerando superfícies, deixando-se imaginar: um exercício de narrativa visual}

Considera-se o corpo que vê com atenção, ouve, degusta, tateia e cheira, mas também o corpo que imagina. A partir do entendimento que "é um enorme equívoco querer fazer da imaginação uma pura e simples faculdade de desrealização" (DidiHuberman, 2012: 208), ela foi tomada como catalisadora da construção de imagens outras que se relacionam com as reflexões sobre as imagens fotográficas evocadas neste percurso.

Assumindo o risco de adentrar pelos territórios da imaginação, ainda havia outros desafios a enfrentar. Por exemplo, o que guiaria a ação de imaginar? Então, o acervo enquanto imagem - imagem de superficie e profusão - acabou por culminar em 
uma narrativa visual da feira enquanto gesto embaralhado, feira-imagem-amálgama. E assim, voltando ao início do texto, dobrando sobre si mesmo. O olhar sobre gestos de feiras embaralhadas fez com que o recorte, que era necessário, se desse em função de interesses que surgiram da relação com as fotografias a posteriori.

A partir dessa inquietação, então a feira-lugar, a feira com nome e história, com coordenada geográfica, diluiu-se nos corpos que a constroem e que ecoam através do tempo e do espaço. Ela se emancipou: feira-gesto, gesto-feira. Passou a ser somente isso: gesto-imagem, imagem-gesto.

Feira sem certidão de nascimento, sem endereço, sem história, que se apresenta em fragmentos congelados produzidos por quaisquer um dos 11 fotógrafos - fotógrafos com nome e sobrenome conhecidos, é verdade - mas desvencilhados inicialmente deles. Esta narrativa visual se submeterá ao objetivo de suscitar provocações acerca da dimensão da experiência e do corpo quando confrontados com a imagem. Uma espécie de cartografia do sensível que almeja discutir a fotografia e a imagem mental em um novo estatuto dentro da produção do conhecimento acadêmico.

Inicialmente, as imagens impressas, no tamanho de $10 \mathrm{~cm} \times 15 \mathrm{~cm}$, estavam nas mãos. Agora as lógicas de associação entre elas podiam se dar de forma mais livre que no computador, e de forma também mais rápida. A mesa não dava conta das fotos espalhadas; migrou-se para o chão. Amontoou-se em blocos, mas uma mesma fotografia podia se avizinhar a várias outras. Os blocos, portanto, passaram a compor conjuntos, mas o método foi insuficiente. As fotografias não podiam ser todas vistas ao mesmo tempo para serem manipuladas, mesmo saindo da casa dos milhares e estando reduzidas a apenas três centenas, elas se faziam ainda um aglomerado indomado, diríamos mesmo selvagem. O caos ainda se instalou e o corpo não acompanhou tal multiplicidade.

Com isso em vista, o ensaio visual, aqui, pôde se colocar como uma possibilidade numa nova ação de embaralhar, mais uma vez destruindo não somente a lógica da tela, onde se colocavam como vizinhos adjacentes, uma fotografia ao lado de outra, mas também a lógica retangular das próprias fotografias impressas.

Então se fez método recortar delas alguns núcleos formais e de significado. Estilhaçar a matéria colorida retangular e trabalhar com os fragmentos. Os gestos, as 
marcas, os elementos principais da cena, mas também os residuais. Tudo aquilo que fora elencado como ponto de interesse, mas também aquilo que simplesmente cativava, eleitos pela intuição ou afeição. As fotos foram dilaceradas, mas os caminhos entre elas se tornaram mais numerosos, frutíferos, próximos.
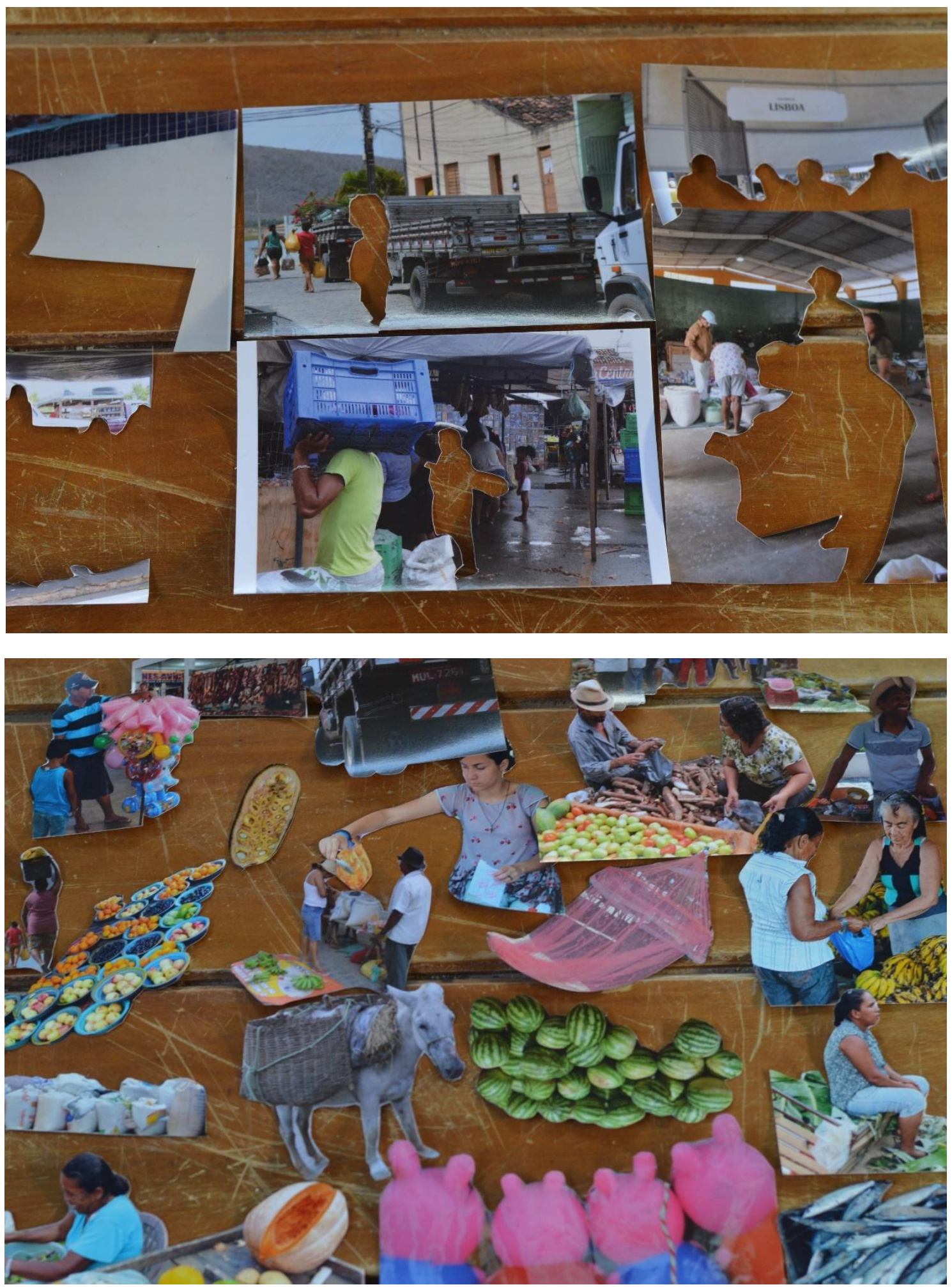

Fonte: Acervo Grupo de Pesquisa Estudos da Paisagem. 
É verdade: perde-se o zoom, fica-se refém da escala fixada na impressão, que causa inusitadas aparências. Uma batata pode ser maior que uma melancia e uma jaca. Uma criança, maior que todos os adultos. Uma galinha, da altura de um caminhão paude-arara. Mas as aproximações entre esses gestos e objetos significantes podem ser mais íntimas. Agora, despedaçando-as, juntando-as numa vizinhança de contiguidades esdrúxulas, na proximidade que muitas vezes a feira instiga, como, por exemplo, quando maxixes se abeiram de calcinhas, e vassouras, de repolhos...
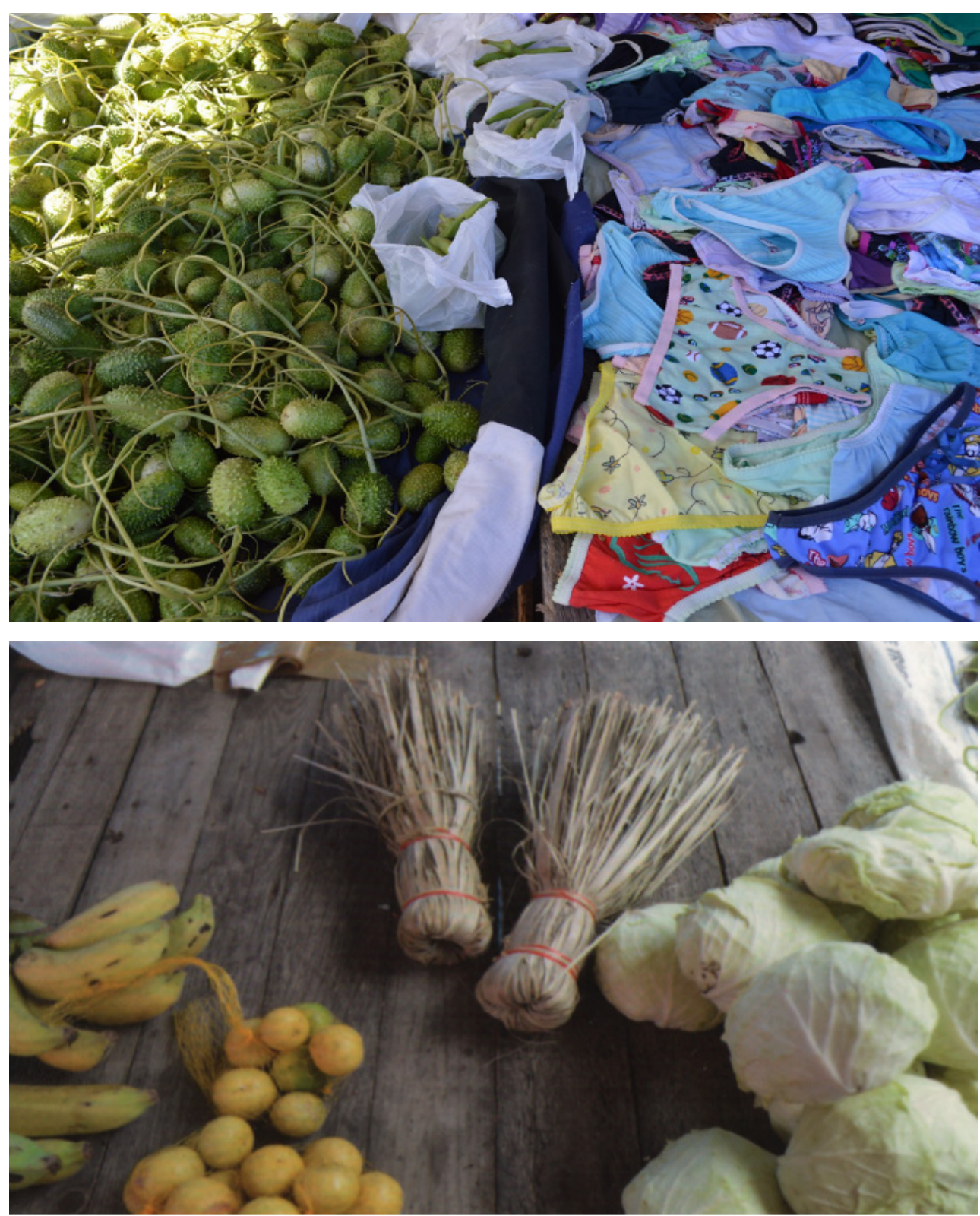

Fonte: Acervo Grupo de Pesquisa Estudos da Paisagem e Instituto do Patrimônio Histórico e Artístico Nacional - AL.

Por fim, voltou-se ao formato retangular como forma de compor novas fotografias através do despedaçamento. E assim, das imagens, fizeram-se montagens. 


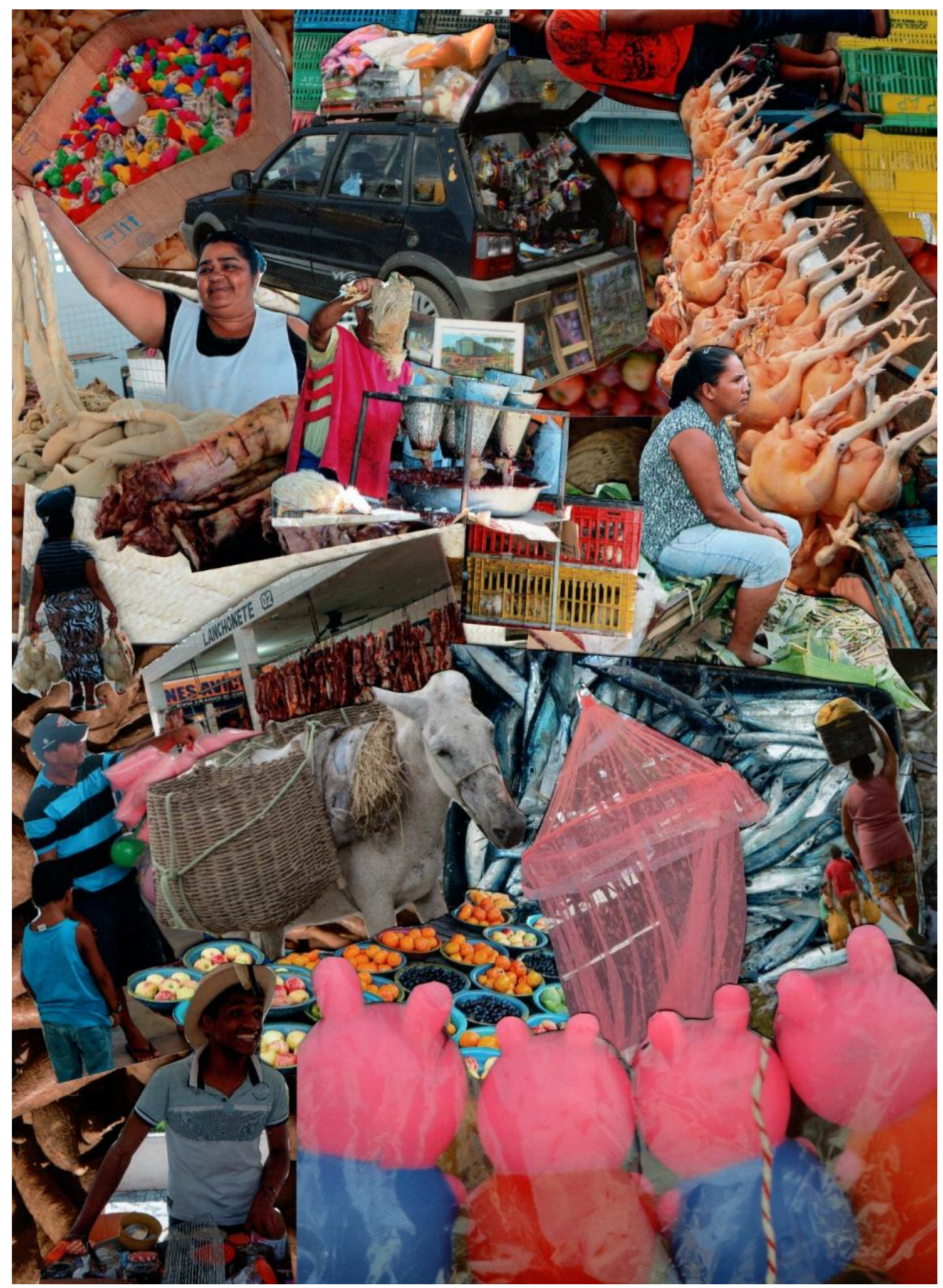

Montagem feita por Louise Cerqueira. As fotografias utilizadas nas montagens são de autoria de Flávia Correia, Janaína Toscano, Karina Mendonça, Ana Karolina Corado, Paula Louise Fernandes, Débora Vital, Alícia Rocha, Maíra Normande, Ludmila Mares, Suzanny Marihá, Naiade Alves, Andressa Alves, Louise Cerqueira, Arlindo Cardoso. Fonte: Acervo Grupo de Pesquisa Estudos da Paisagem e Instituto do Patrimônio Histórico e Artístico Nacional - AL. 


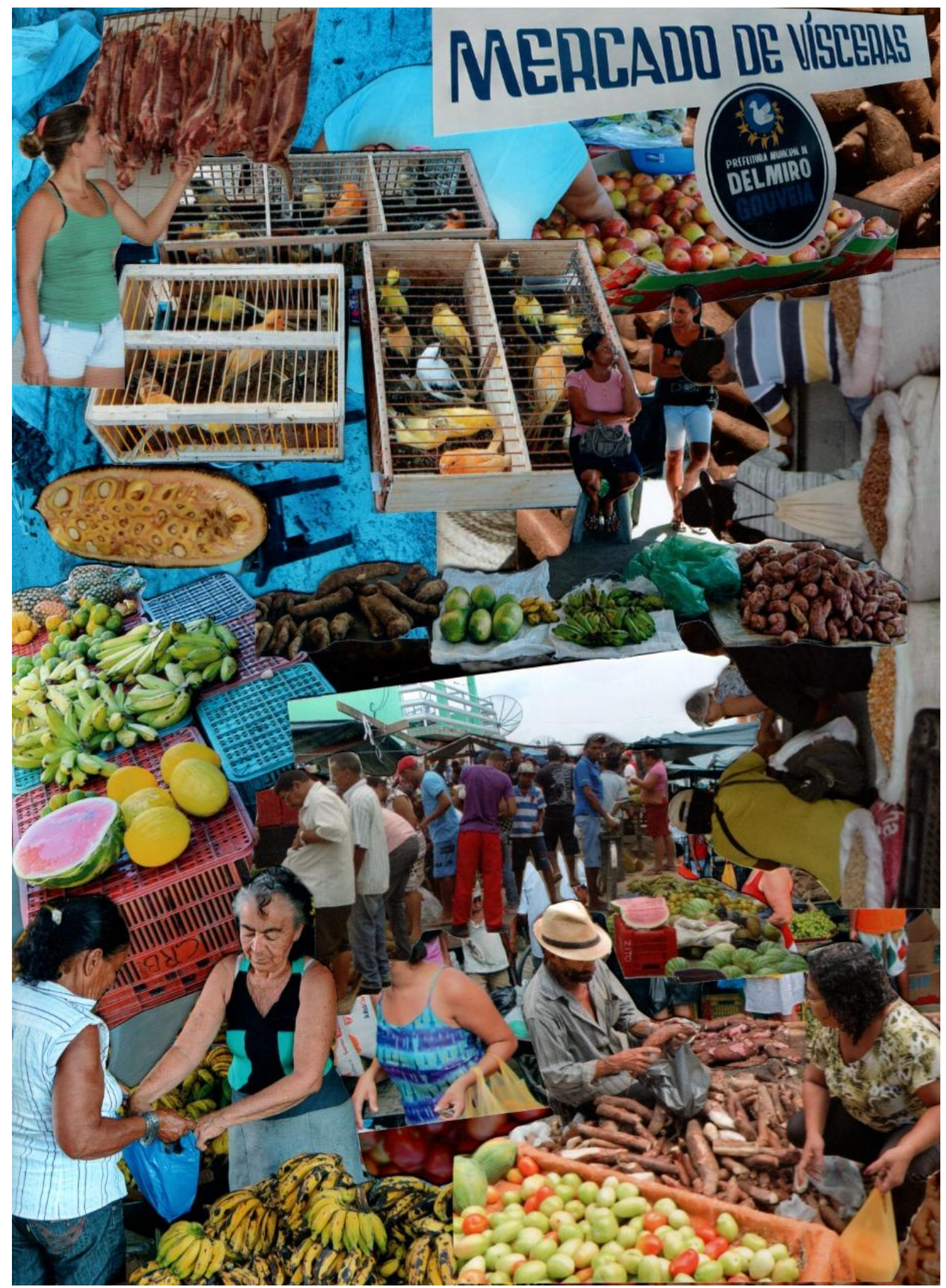

Montagem feita por Louise Cerqueira. As fotografias utilizadas nas montagens são de autoria de Flávia Correia, Janaína Toscano, Karina Mendonça, Ana Karolina Corado, Paula Louise Fernandes, Débora Vital, Alícia Rocha, Maíra Normande, Ludmila Mares, Suzanny Marihá, Naiade Alves, Andressa Alves, Louise Cerqueira, Arlindo Cardoso. Fonte: Acervo Grupo de Pesquisa Estudos da Paisagem e Instituto do Patrimônio Histórico e Artístico Nacional - AL. 


\section{Considerações}

Neste artigo, buscou-se enfrentar o desafio de considerar um acervo imagético como um recurso proporcionador do prolongamento da memória de uma experiência empírica. De derivar com o olhar, de pensar a imagem para além da representação. De pensar a profusão e a superficialidade como desafios metodológicos que valem a pena ser enfrentados, refletindo sobre a importância do corpo e da imaginação no escopo de um trabalho com imagens. Portanto, aqui, a quantidade não se fez quesito que respaldasse uma maior eficiência na análise a ser realizada.

Partiu-se da imagem como fonte de interpretação, a qual não está apartada do universo amostral de experiências coletadas anteriormente, sendo em alguns casos o gatilho que provocou a relação com a fotografia, que a destaca da mancheia de outras imagens e desperta para a questão da sensibilidade do pesquisador em ação no campo.

O ensaio visual que conclui estas breves reflexões, buscou utilizar a linguagem de recorte como laboratório para condensar a vastidão em um experimento artístico que mantivesse a profusão em uma síntese da deriva ótica, ressaltando os gestos identificados como formadores das feiras livres, gestos estes não apenas enquadrados nas fotografias mas também aludidos através das marcas nos objetos, nos espaços, nos animais. A manipulação material das fotografias impressas cria uma narrativa que se revela também como gesto visual enunciador, deliberado, com propósito e escolhas que conferem possíveis sentidos à montagem.

Com a construção de narrativas, buscou-se trazer aspectos prementes sobre a pesquisa nas feiras livres. Pesquisa essa que embala o corpo sensível e a imaginação a entrarem na relação que, a priori, parece apenas visual, quando se mira o acervo como um todo, ou, ao contrário, parece excluir a visão, como no caso da reflexão sobre os cheiros, que revela presença na ausência. Sato (2012), que escreveu uma tese sobre as feiras livres a partir do campo da psicologia social, questionara-se sobre o aspecto invasivo do próprio ato de pesquisar. "Será que posso, devo e preciso olhar tudo? Será que posso, devo e preciso perguntar sobre tudo? Será que posso, devo e preciso ouvir tudo?” (2012: 26). Pergunta-se aqui: será que se pode, deve e precisa fotografar tudo? 
Mais que isso: não se trata apenas de dever ou não registrar, mas do aspecto do congelamento da fotografia prolongar o olhar de um mero instante vivido. Será que se pode, deve e precisa olhar todos os detalhes de uma fotografia? Porque a imagem proporciona a oportunidade de ver demoradamente, de fazer escrutínio com a vantagem de ter, diante de si, o tempo paralisado. De enxergar o que escapou à percepção da vivência durante momento, mas foi capturado pelo sensor. Permite o zoom que nos faz aproximar muito mais do que a distância da presença pessoal jamais permitiria - ver bem de perto uma textura ou um detalhe no fundo da foto. Porque captura a imagem do outro e a lega indefinidamente. Por anos, e por cópias.

A fotografia traz para si a imagem do outro. Todas as pessoas fotografadas no acervo são hoje imagens. São hoje sujeitos-objetos de estudo, de fito, do olhar. O que acontece quando um ser humano é reduzido à imagem? Reformulando a pergunta, o que acontece quando é potencializado, quando é amplificado à imagem? Ou não seríamos já todos imagens, pois, como disse Manguel (2006: 21), "assim como as palavras, [as imagens] são a matéria de que somos feitos"?

\section{REFERÊNCIAS}

BARROS, Manoel de. Poesia completa. São Paulo: Leya, 2010.

BARTHES, Roland. A câmara clara: nota sobre a fotografia. Lisboa: Edições 70, 2006.

BENJAMIN, Walter. A obra de arte na era de sua reprodutibilidade técnica.

CORBIN, Alain. Saberes e odores: o olfato e o imaginário social nos séculos dezoito e dezenove. Tradução: Ligia Watanabe. São Paulo: Companhia das Letras, 1987.

DIDI-HUBERMAN. Cascas. Trad: André Telles. São Paulo: Editora 34, 2017 . Quando as imagens tocam o real. Trad: Patrícia Carmello e Vera Casa Nova. Pós: Belo Horizonte, v. 2, n. 4, p. 204 - 219, nov. 2012. Encontrado em: https://www.eba.ufmg.br/revistapos/index.php/pos/article/view/60/62 Acesso: 03 fev 2019.

Pensar debruçado. Trad. V. Brito, ed. J. F. Figueira e V. Silva. KKYM, 2015 DUBOIS, Philippe. O ato fotográfico e outros ensaios. Tradução: Marina Appenzeller. Campinas: Papirus, 2012. 
FOUCAULT, Michel. As palavras e as coisas. Tradução: Salma Tannus Muchail. 9 ed. São Paulo: Martins Fontes, 2007.

FLUSSER, V. Gestos. São Paulo: Anablume, 2014.

GINZBURG, Carlo. Mitos, emblemas e sinais. Morfologia e história. Tradução: Frederico Carotti. São Paulo: Companhia das Letras, 1989.

GONCCALVES, José R. S. Ressonância, materialidade e subjetividade: as culturas como patrimônios. In: Horizontes Antropológicos, Porto Alegre, ano 11, n. 23, p. 15-36, jan/jun 2005.

IPHAN. Inventário nacional de referências culturais: manual de aplicação. Apresentação de Célia Maria Corsino. Introdução de Antônio Augusto Arantes Neto. - Brasília: Instituto do Patrimônio Histórico e Artístico Nacional, 2000.

MALNIC, Bettina. O cheiro das coisas: o sentido do olfato: paladar, emoções $e$ comportamentos. Rio de Janeiro: Vieira \& Lent, 2008INRC. Manual. Relatório Final.

MANGUEL, Alberto. Lendo Imagens: uma história de amor e ódio. Trad: Rubens Figueiredo, Rosaura Eichemberg, Claudia Strauch. São Paulo: Companhia das Letras, 2001.

MORIN, Edgar. Introdução ao pensamento complexo. Tradução: Eliane Lisboa. Porto Alegre: Sulina, 2005.

MORTIMER, Junia. Pensar por imagens. In: JACQUES, Paola B.; PEREIRA, Margareth da S. Nebulosas do Pensamento Urbanístico. Salvador: EDUFBA, 2018. P. 156-175.

NÓBREGA, T. P. Uma Fenomenologia do Corpo. São Paulo: Ed. Livraria da Física, 2010.

RIBEIRO, A. C. T. Homens lentos, Opacidades e Rugosidades. In: BRITTO, F. D.; JACQUES, P. B. REDOBRA 9, Salvador: Cian Gráfica Editora Ltda, 2012. p. 58-71.

RIBEIRO, A.C.T. Cartografia da ação social: Região latino-americana e novo desenvolvimento urbano. In: Hector Poggiese; Tamara Tania Cohen Egler. (Org.). Otro desarrollo urbano: ciudad incluyente, justicia social y gestión democratica. Buenos Aires: CLACSO, 2009, v. , p. 147-156.

SAMAIN, E. G. Como pensam as imagens. Campinas: Editora da Unicamp, 2012. E-book.

SATO, L. Feira livre: organização, trabalho e sociabilidade. São Paulo: Editora da Universidade de São Paulo, 2012.

SANTOS, Milton. Técnica, Espaço, Tempo: Globalização e meio técnico-científico informacional. São Paulo: Hucitec, 1994.

Recebido: $10 / 02 / 2020$

Aprovado: 15/07/2020 